\title{
Restitution versus Populism: Revisiting the Dominant Tropes of the Land Question in Zimbabwe
}

\author{
Langton Makuwerere Dube \\ School of Government, Sun Yat-sen University, Guangzhou, China \\ Email: langtonmdube@hotmail.com
}

How to cite this paper: Dube, L.M. (2019) Restitution versus Populism: Revisiting the Dominant Tropes of the Land Question in Zimbabwe. Open Journal of Social Sciences, 7, 203-219.

https://doi.org/10.4236/jss.2019.710017

Received: September 4, 2019

Accepted: October 19, 2019

Published: October 22, 2019

Copyright $\odot 2019$ by author(s) and Scientific Research Publishing Inc. This work is licensed under the Creative Commons Attribution International License (CC BY 4.0).

http://creativecommons.org/licenses/by/4.0/

\section{c) (i) Open Access}

\begin{abstract}
Zimbabwe's land revolution at the turn of the millennia cast the country on the international spotlight for a myriad of reasons, ranging from laudatory admiration to negative criticism and bad publicity. Narratives and doomsday predictions of economic disaster, social upheaval and ultimately internal implosion were awash and not off the mark given the manner in which the political economic status quo was shaken and restructured. The Fast Track Land Reform (FTLRP) was hailed in some quarters as the long overdue corrective measure against historical injustices while other sections castigated it as chauvinistic and fascist machinations of a capricious regime battling for political survival. These ensuing contestations around land expropriation are not an aberration in that they form part of a repertoire of the languages of life and/or the teleology in the history and transition of post colonies with settler heritage. Land reform continues to gain policy traction in much of the developing South with a colonial history where the economic logic of settlerism was the dominant mode of exploitation, expropriation and accumulation. Widening inequality in much of the developing South particularly in post settler economies in southern Africa has heightened demands for greater access to land and other productive sectors putting land as another new frontier of conflict. Therefore the question remains, is land reform being driven by a genuine desire for restitution and a progressive redress of colonial wrongs or whether it is just another pretext for populist demagoguery and patronage politics? This paper posits that these two dominant tropes are deeply interwoven within Zimbabwe's political economics fabric within its transition as a post colony and the matter is much more complex and cannot be reduced to such binary terms of reference. The paper therefore traces the trajectory of land reform in Zimbabwe since independence until the turn of the millennia and the attendant policy contradictions, constraints and rationalities that undergird land expropriation and redistribution.
\end{abstract}




\section{Keywords}

Land Question, Restitution, Populism, Zimbabwe, Land Redistribution

\section{Background}

Events at the turn of the millennia in Zimbabwe and the broader socio, economic and political context in which they have manifested themselves have been transformational, revolutionary and dramatic. Zimbabwe's FTLRP suffered negative press publicity, with images of chaos, destruction and violence dominating the headlines. The land issue in Zimbabwe has its roots in the colonial period of conquest and subjugation. Beginning in the 1890s, the incoming white settlers dispossessed and alienated, without compensation, the native African tribes chiefly the Ndebele and the Shona tribes from their lands [1] [2].

Elsewhere across the world, from the neo Europes of North America, the Antipodes and to the Spanish colonies of Mexico, the Andean Cordillera and the rest of South America, colonialism was never a terrain for democracy, racial inclusion or tolerance. Thus, in all these locales colonialism carried the same traits of racial segregation and a systematic violence that was epistemic to the aborigines and their autochthonous claims either material or cultural. In the new Zimbabwe, the passing down of pernicious and exclusionary legislation by subsequent colonial governments along racial lines, like the Land Apportionment Act of 1930, Land Husbandry Act of 1951 and the Land Tenure Act of 1969 among others further entrenched colonial settler privilege that widened the gulf between the races. The logic of colonialism was hugely hinged on violence, plunder, force, indigenous subjugation and servitude [3] [4]. Its identity manifested itself in land alienation through systematic and legalized land policies of racial oppression and exclusion which entrenched a dual agrarian land regime of private land for whites and communal lands for the native indigenes [5] [6]. It is therefore not surprising that the land question became a central motif of nationalist discourse in the 1950s leading to the Second Chimurenga or War of Uprising against colonialism which culminated with the dawn of national independence in 1980.

Henceforth, land policy in post colonial Zimbabwe eschewed the need to open access for the indigenous blacks, to the productive sectors of the economy from whence they had hitherto been physically and emotionally marginalized. It was a way of fighting poverty and improving rural livelihoods as it was also a way of providing restitution against the enduring vestiges of colonialism. Therefore in general, the policy thrust of the new administration at independence envisioned a changing of the racial composition of access of land holding sizes, land use norms and tenure systems which were a result of colonial privileges surrounding land access, tenure and production systems [7] [8] [9] [10]. The moments at which liberation movements come to power is normally one of extraordinary 
catharsis and the new state will be buoyed by the legitimacy that comes along with it [11], and Zimbabwe's experience is by no means different. However there are immediate challenges that are always inherent in the transitional phase which include the problems of stabilization and reconstruction, demobilization and reintegration of former freedom fighters into the society, the creation of an effective and trained bureaucracy, the self transformation of the liberation movement into a functioning government and most importantly the pressure from the citizenry for the new government to meet the expectations as engendered by the liberation. The new Government of Zimbabwe (GoZ) was faced with difficult policy choices of trying to strike a balance between white capital and indigenous capital, maintaining the sustainability of the already functional economy while at the same time embarking on redistributive measures for restitution [10]. Powerful economic structures inherited form the colonial era stood in opposition to the aspirations of the movement especially with respect to agricultural land which was by far the central issue for the rural population whose support was so critical for the Movement [11].

Consequently, despite some land being redistributed during the first two decades of independence, policy traction was very slow for a variety of reasons which this paper will seek to elaborate. By 1999 approximately six million people lived in Zimbabwe's marginal rural lands characterized by poor soils and unreliable and erratic rainfall where producers were physically, structurally and emotionally crowded out, not only from land and its agriculture value chain, but also from the commanding heights of the economy and the bulk of the nation's natural resource base [2] [12]. The ensuing racially invoked affluence gap where white agrarian interests hamstrung the whole economy pointed to the unchanged legacies of colonial heritage, stark reminders of a dark age, and living memories of the deep scars that were indelibly engraved on native conscience that had to be erased [13].

\section{Statement of the Problem}

Land reform is a sacrosanct process in most post settler economies in view of the colonial history of land dispossession and concentration along racial lines which systematically and structurally marginalized the native indigenes from any meaningful process of primitive accumulation and socioeconomic mobility. Land reform especially land expropriation and redistribution becomes very fundamental as an affirmative action policy for poverty alleviation and the reordering of social relationships of power, pride, wealth and affluence. Demands for land reform are more acute in situations where the systems that used to undergird colonial structures of power and domination remain in place many years after independence, where land as the abode of all natural resources remain in the hands of an obdurate and privileged white minority. For 17 years dating back to 1980, Zimbabwe embarked on land reform with mixed results until finally engaging in a radical land expropriation and redistribution wherein white farmers 
were dispossessed of their farms and the land was redistributed to black Zimbabweans.

The land redistribution generated so much controversy and divided opinion leading to unprecedented levels of polarization. Along the continuum, the program has been dismissed as a carefully designed political scheme to retain power, a populist gamesmanship to create constituent dependencies and to silence discontent from within by using land as a patronage tool. In addition, allegations are that, land reform was manipulated as a way of discrediting political opponents' thereby revitalizing plummeting regime legitimacy. On the contrary, land reform has been hailed as a corrective measure against the entrenched legacies of historical injustices that were a result of colonialism. Land reform assumes a restitutive garb in decimating unequal access to land and the productive sectors of the economy thereby opening access to those formerly excluded. It was labeled the final step in the consolidation of total independence which should be reinforced by economic emancipation and empowerment. Such a dual and polarized assessment of the program is grossly misleading or rather shallow typical of cavalier examinations, devoid of the historical depth of "longue duree" and is uncharacteristically diluted by the shallowness and divisiveness of political sloganeering and whose main purpose is social engineering. Such a polarized and binarised depiction of land reform hollows out the middle ground between the two strands of argument and is not only an affront to the historiography of land reform in Zimbabwe but also the veracity of empirical analysis thereof.

This study starts from the premise that while these two diverging viewpoints form part of the reality, land reform in Zimbabwe requires a much deeper analysis than such a binary polarized debate. Land reform in Zimbabwe and elsewhere is a process and not an event, as such it requires an understanding not only of the history of land in Zimbabwe, but also the transition of Zimbabwe as a post colony. This study calls for an in depth critique of the neocolonial logics of power and exploitation as they interacted in the country's political economics. The Zimbabwean narrative is much more complex and to subject it to the two benchmarks would be hypocritical and tantamount to a dismissal of history. This paper therefore holistically traces the land reform trajectory in Zimbabwe to unravel the interplay of a myriad of factors which had a major impact on the nature and inertia of reform in the end generating controversy.

\section{Research Questions}

Because of the importance of land reform in post settler economies, this paper provides insights into the overarching question of whether land reform is for restitution or political mileage?; what role does land reform play in post settler economies?; why was land reform important in Zimbabwe?, what were the rationalities and contradictions that influenced redistribution in Zimbabwe?, who were the beneficiaries of the redistributive exercise among others. It follows that a critical examination of these questions provides insights into the complex character and entangled politics surrounding land redistribution in Zimbabwe. 


\section{The Trajectory of Land Reform since Independence}

The paper will not delve deeper into the subtleties of land grab during the era of colonial entrenchment save to mention that there was a systematic land displacement, one that deprived the natives of access not only to land but to the rest of the productive value system. At independence therefore, the grotesque picture on the walls depicted some deeply entrenched introverted and extroverted economic interests spanning across the agrarian, mining and industrial sectors which remained under the monopoly of white capital. Approximately 6000 white Large Scale Commercial Farmers (LSCF) had access to control and user rights of land under Freehold tenure of 39\% (15.5 million hectares) of prime farmlands across the breadth of Zimbabwe. In contrast, roughly close to 1 million natives remained attached to $14.4 \%$ (16.4 million hectares) of marginalized lands not conducive for any form of biota. Therefore, a white minority constituting about $3 \%$ of the total population of Zimbabwe controlled two-thirds of national income [7] [14]. Despite this grim portrayal, Zimbabwe's economy was industrially second only to that of its neighbor Apartheid South Africa then, with a sophisticated Agro industrial complex where half the industrial output fed domestic consumption. The associated value chain included a variety of products ranging from clothing, fertilizers, lime, chemicals, metal products, electrical goods, armaments among other commodities [10]. The Lancaster House Conference that brought together the warring parties to the negotiating table and gave birth to liberation failed to adequately address the land issue. The debate surrounding the land question and the spirited attempts to resolve it through market instruments under the willing buyer willing seller concept and its associated inertia failed to redress the colonial legacy consisting of grossly inequitable land redistribution [2] [14] [15].

The Land Question was partially resolved at Lancaster House Conference in 1979, a negotiated settlement that brought about a cessation of conflict and ultimately Zimbabwe's Independence the following year in 1980. The Sunset Clauses granted special protections to white Zimbabweans for the first ten years of independence and restricted the Government of Zimbabwe (GoZ) from effecting any compulsory land acquisitions. Land reform according to the agreement was to be carried out under the auspices of the market through the "willing buyer willing seller" setup [14] [16]. Pledges were made by the British and American governments that they would fund the whole process of land reform for the first 10 years of independence as per the agreement under the Lancaster talks. However, very little activity occurred under the willing buyer willing seller arrangement for various reasons ranging from the unavailability of enough funds because the British and American governments did not fulfill their pledges as part of the bargain. In addition, very few farmers were willing to part with their land hence the land available to government if there was any, was very little either in those areas of low agricultural potential and poor economic viability or those farms that were abandoned during the war or sold by the few farmers who left at Independence [17] [18]. 
At Independence Zimbabwe was under borrowed with a debt ratio of $10 \%$ but astonishingly ballooned to $32 \%$ by 1982 [19]. Zimbabwe entered a balance of payment crisis as early as 1982 and thus her economic policies became a dictate by the IMF [19] [20] [21]. This had the negative effect of forcing the government to cut back on rural spending and land resettlement among other priorities altogether which was against its welfarist policy agenda adopted at independence as a way of bridging the wide affluence schism that existed between the races. Because of the aforementioned reasons, very little activity as alluded earlier occurred under the First Phase of land reform partly due to the constitutional constraints set by the 1979 Lancaster House Agreement [14], the poor budgetary planning and provisioning from the perspective and the GoZ's obligations of financing the supporting infrastructure. Land reform program lost momentum during the mid 80s and resurfaced at the policy agenda at the end of the decade against a backdrop of the formation of the first vibrant but short-lived opposition party, the Zimbabwe Unity Movement (ZUM). These years were characterized by a growing disillusionment on the part of the peasants and landless poor over the inertia of land redistribution and the urbanites that were beginning to feel the strain of the austerity associated with the ESAP.

Despite the brief hiatus on the urgency of land reform by the government, land occupation by the landless continued at a lower scale but over time had the potential to threaten the legitimacy of the government for it would be an indictment that the Movement has failed to live up to the promise [22]. Reports of illegal land invasions and squatter settlements by disgruntled landless peasants became very common but the government was quick to send law enforcements to evict them [10]. The market led land reform during the first ten years of independence failed to meet its targets because it was too incremental and slow and that the land on offer was of no high economic value mostly in the periphery. Most importantly the funding from the British government of only US44 million was too little given the scale of the reform at hand in the end creating becoming a source of a diplomatic row between Harare and London [10].

The year 1990 signaled the expiry of the willing buyer willing seller principle and pushed the GoZ to promulgate the Land Acquisition Act of 1992 through Amendment Number 11 to the Constitution which stated that all land was subject to acquisition, not just underutilised land and that all land offered for sale should be offered to the government first before being sold to a third party (the right of first refusal). The government was further obliged to pay a fair compensation within a reasonable time not a prompt as has been under the willing buyer-willing seller era. However reform inertia was very minimal because the government was severely constrained by the socio, political and economic effects of austerity. The government managed to resettle only 20,000 families on an acquired 80,000 hectares and lawsuits by farmers became another huge constrain during this period [23]. Redistribution was also marred by strong allegations of elite capture of the process by those individuals by politicians, political acolytes or those with political capital [14] [16]. 
The end of the 1980s decade heralded the collapse of Socialism as an ideology with the disintegration of its last standing bastion, the Union of Soviet Socialist Republics (USSR) and the end of the Cold War altogether. This marked the triumph of liberalism through the adoption of one size fits all, straight jacket dictates of the Washington Consensus driven Economic Structural Adjustment Programs (ESAP) of the IMF and WB. The adoption of the ESAP created tension across the socio-economic and political space as a result of the effects of the austerity measures and the attendant dramatic volatility, vulnerability in many markets coupled with deindustrialization and underdevelopment [24]. The years witnessed sustained affirmative action by the indigenous business lobby for access to the white dominated markets and financial institutions and increasing trade union militancy calling for improved conditions of service through strike activities that were hemorrhaging the economy.

As was the case elsewhere on the continent where ESAP was implemented, the Zimbabwean economy that had been growing at an annual average rate of 3.8\% between 1980 and 1989 had gone down to 0.5\% [7]. The economy continued on a freefall, punctuated by terrifying financial meltdowns and a spectacular crash of the currency ( $55 \%$ for the year as a whole but $75 \%$ in a few hours on Black Friday-14 November 1997), dramatic increase in interest rates (6\% within one month), plummeting stock market which led to an unprecedented fiscal stress [20]. A decision by the government to pay off registered war veterans a staggering $Z \$ 50,000$ each plus a $Z \$ 2000$ monthly pension coupled with the country's intervention in the Democratic Republic of the Congo war was a budget buster and a further drain on the weak fiscus. The social and economic effects of austerity in the 1990s decade gradually led to the conflation between trade unionism and political activism when the biggest trade union umbrella organ the Zimbabwe Congress of Trade Unions (ZCTU) morphed into a fully fledged political party, the Movement for Democratic Change (MDC). The formation of the MDC in 1999 and its impressive performance in the 2000 Referendum was just the beginning of confrontational politics in Zimbabwean history. Sensing a direct threat to its political survival and legitimacy, the ruling party ZANU PF led government resorted to the emotive land issue in a desperate bid to boost domestic populism [25].

That said, it is crucial to point out that fundamental reservations were raised over the political manipulation of the land question, pervasive criminal and opportunistic elements that defined the whole process. Questions have been raised about the real motives behind the land reforms in Zimbabwe. It has been argued that the prospect of receiving land played well with the peasants, that the expropriation of white farms did put fresh booty into the patronage system starved of resources [26] [27] [28] [29] and options or that it was a genuine desire on $\mathrm{Mu}$ gabe's part to inaugurate a new and profound stage of decolonization before he exits the political stage. Zimbabwe's land reform, the subsequent socio-political and economic conundrum and national invalidation has polarized literature through ideological positions that have trumped empirical analysis of the emo- 
tive subject. Some have sought to analyze the whole subject as a direct consequence of either, megalomania and corruption [26] [30] and or unsustainable economic policies exacerbated by structural adjustment policies and the resultant globalization drive [24].

\section{Land Redistribution as a Strategic Tool to Destroy Political Rivals}

The events surrounding Zimbabwe's land reform and the rationalities and the trajectories that it took have to be understood within the political contestations that ensued between the ruling party Zimbabwe African National Union Patriotic Front (ZANU PF) and the newly emergent opposition party, the Movement for Democratic Change (MDC). The socio-economic morass of the 1990s decade and incessant pressure to live to the promise of redistribution from the war ex-combatants within the ruling party was threatening the very core foundations of the party both from within and outside [1]. The meteoric rise of the MDC, a neoliberal party and its class based urban following galvanized by support from the white community in Zimbabwe and the international community inclusive of the British and American governments gave ZANU PF the pretext to embark on a combative nationalist policy [31].

The MDC was opposed to compulsory acquisition of land without compensation and was advocating for a market based approach to land reform. At its formation, the MDC was vehemently opposed to the continuous existence of the Lancaster House Constitution and was agitating for a new constitution which the ZANU PF agreed under duress because of domestic pressure. Therefore the litmus test for the regime legitimacy was the February 2000 Referendum for a new constitution, which had among other salient issues, the clause for compulsory acquisition of land without compensation and one that sought to increase Presidential powers. The proposed constitution was rejected and to further compound the situation, the new MDC managed to garner 57 seats out of the available 120 parliamentary seats in the general election in the year 2000 and this jolted ZANU PF out of its wits. The electoral result in the 2000 Referendum was a direct rejection to the ruling party ZANU PF by the electorate, a divorce from the holy matrimony between the masses and the party that had been conditioned by the trials and tribulations of the vagaries of colonialism and one that was supposed to last as far as it could as a self fulfilling prophecy of the messianic stature of the liberators. For the first time in the history of post independence politics, ZANU PF's hegemony was under serious threat from a political movement that threatened to pull the carpet from under its feet. Land reform therefore, was a deliberate attempt to punish the MDC and its supporters especially the white farmers who had actively campaigned against the Referendum and most whom were funding the opposition and providing a myriad of logistical support [26] [27] [28] [30]. The white community had violated their subtle agreement made in sufferance with ZANU PF government wherein they were allowed to work for the good of the nation, to have their property rights on farms respected as long 
as they were going to stay out of politics [31]. Because they reneged on that, the nationalist government decided to punish them for their intransigence hence the land expropriation.

In light of the foregoing, the fact that the MDC attracted white support and funding both from the white farmers and sympathy from the British government ignited and reactivated anti colonial struggle consciousness and its racial prejudice within the nationalist liberation government. From ZANU PF's vantage point, land reform became another theater in which neo colonialist forces were attempting to reverse the gains of independence by infiltrating national politics. This gave birth to the land policy which [32] summed up as "both violent and divisive and accompanied by a virulent nationalism". That which came to be known as patriotic nationalism and that was hinged on "Othering" between pro government apologists as patriots, selfless cadres, nationalists and son of the soils and the opposition supporters as sellouts, western stooges, saboteurs and enemies of the nation among others. Battle lines were drawn and as always with nationalist movements and their "struggle consciousness" [11], the FTLRP was from then on dubbed the "Third Chimurenga", in pursuance of the First Chimurenga war of colonial resistance in the 1890s, the Second Chimurenga armed struggle (1960s to 70s) culminating in the dawn of independence in 1980. It follows therefore that the land invasions were aptly named the Third Chimurenga to imply the final and penultimate stage of independence from colonial domination, a logic that was highly premised on the belief that political independence alone and its hoisting of the national flag was a half baked cake, therefore if had to be galvanized by liberation from the economic tentacles of neocolonialism, whose lifespan had somehow persisted into the post colonial era. This so called Third Chimurenga invoked the memories of the war of liberation and had the image of posturing Zimbabwe as being a target of neo-imperialism hence ZANU PF campaigned in the 2000 Parliamentary elections under the manifesto, "The land is the Economy and the Economy is the Land" which subsequently put Land as a central motif not only in the electoral season but in the whole tapestry of the social, political and economic lifeblood of the nation in the subsequent years. The divisive character of land reform created a dangerous rupture in Zimbabwean political discourse. The endgame was to discredit the MDC as another Trojan horse of imperialist forces whose main mission was to derail the pan African project of sustainable socio-economic development that empowers the indigenes. Hence terms like "national sovereignty", "territorial integrity", "Zimbabwe shall never be a colony again" became verbal staple.

\section{Redistribution as a Strategic Tool for Political Power Consolidation}

Land expropriation and redistribution under the FTLRP can be conceptualized through Bucheli and Decker's line of argument that depicts a high level of intimacy between economic conditions and political survival that pivots the proliferation of economic nationalism in developing countries [33]. "The theory of po- 
litical survival posits that the rationale behind economic policies rulers or ruling elites develop is to ensure the loyalty of those groups that guarantee the said ruler or ruling party's political survival. This means a ruler might support an economic policy that does not favor the economy, but ensures his or her political survival" [33]. This line of thinking dovetails well with the neo-patrimonialist theory that is firmly premised on the avaricious patron client networks which are perpetrated by elites with an insatiable appetite for accumulation and a deep sense of entitlement that is so deeply ingrained and engraved in the conscience of the nationalist movements and their surrogates.

In view of the foregoing, the land redistribution has been viewed along patron client lenses as a populist gesture wherein political surrogates, ZANU PF acolytes, cronies, henchman, palace apologists and party "beni ouis ouis" were being rewarded with fresh booty along patronage lines hence the emotive land issue played the role of political hedge fund at a time when the ruling party legitimacy was under serious threat. There has been reports in scholarly circles that most of the beneficiaries of land redistribution were party cronies, to some extent, that proposition holds water but only as far as it can go. It is a bit of a stretch to imagine an approximate figure of 400,000 land beneficiaries all being cronies with political capital as the glue binding them, because such a scenario would be unprecedented in human history [34]. Be that as it may, because of the politically charged atmosphere that was obtaining, the assertion remains true to some considerable extent that some land reform beneficiaries were ZANU PF supporters and functionaries.

A cursory flashback into the tumultuous 1990s decade will unravel the deleterious effects of austerity, the erosion of socio-economic safety nets for the poor and urban working class, the unbudgeted payments of financial compensation to War Veterans coupled with the military incursion into the Democratic Republic of the Congo (DRC) which resulted in acute fiscal stress and a potential crisis of legitimacy for the government. The war veterans constituency within the ZANU PF party has always been a very powerful force given that most of those who made up the military wings of the liberation movements, that is; Zimbabwe National Liberation Army (ZANLA, military wing of ZANU) and the Zimbabwe People's Revolutionary Army (ZIPRA, military wing of ZAPU), continued to make up a huge population within State structures as bureaucrats or servicemen in the uniformed forces. Since independence, this cohort had grown weary, anxious and restless because of the government's failure to expedite compensation for their immense sacrifice in the struggle for liberation. A significant number of these veterans of the liberation struggle were wallowing in poverty which further strengthened the calls for compensation notwithstanding the fact that compensation was supposed to be extended as a matter of principle not as conditional on economic status.

The 1990s were a decade of economic contraction and mixed fortunes and the war veterans were not spared either from the debilitating effects of the IMF and WB induced structural adjustment austerity measures which further heightened 
calls for their cause. The political costs of not heeding to such calls would be catastrophic for ZANU PF's internal cohesion, competitiveness and ultimately its stranglehold on power. Hence, the close relationship between economic conditions and political survival according to [33] partly explains why the War Veterans had to be paid in haste and when they demanded land, the governing elites were left frozen by circumstances because any attempts to delay or otherwise would have created a crisis of legitimacy let alone the internal implosion of the party because of the class based conflict and differentiation that underpinned the demands.

On another perspective, [35] in his comparative piece on Namibia and Zimbabwe notes a disturbing trend where the two ruling parties, that is South West African People's Organisation (SWAPO) and ZANU PF respectively have instrumentalised the land question through the anti imperialist dogma as a treacherous attempt to divert people's attention from an acute dearth in service delivery and the general economic and material well being of their respective populations [35]. The argument is that, the land issue is a long historic fault line in post settler polities and in the case of Zimbabwe it has been instrumentalised for political expediency at various stages in the country's post colonial transition. Accusations are that since independence, the government had a penchant for making noise about land reform when it was election season presumably taking advantage of its emotive nature as a legitimate grievance that they could draw on to ensure political victory and when the season passes the noise would die a natural death. Therefore the narrative was that land was potent ammunition in ZANU PF's reserve armoury, that it could resort to if need arise and when in the year 2000, a new political outfit (the MDC) with vibrancy and vigor entered the political fray coupled with internal pressures from war veterans from within the liberation party threatening to turn the tables and subvert the political life of the former liberation movement, ZANU PF resorted to its arsenal by instrumentalising a genuine, long held national grievance for its power retention scheme [26] [27] [31].

While the above mentioned narrative captures another strand of thought, it is too simplistic and pedestrian in that it fails to locate the land issue in Zimbabwe from a historical position and the complex nature of its entangled politics in the country's transition [2] [14]. Such a simplistic critique of analyzing the land issue through the dogmatic lenses of populism and nothing else is very problematic. It smacks of selective amnesia by downplaying a grave injustice or what could be termed "constitutionalised injustice" whereby a minority of Large Scale Commercial Farmers (LSCF) most of the predominantly white [36], had user and ownership rights to large tracts of land compared to their black counterparts who had been dispossessed since colonial times and who perpetually were structurally cordoned off from the productive sectors of the economy. To totally subscribe to the assertion of the populist motives of land redistribution is intoxicating dishonesty at best, a façade, a veneer and a bad faith at worst [37], one that is bend on masking the epistemic identity of global coloniality and its in- 
ternational matrices of power and domination as both contingent and violent against antipodal political and ideological ideals [38] [39].

Therefore the argument that the government was not interested about land reform per se but only sacrificed the land issue on the altar of political expediency is highly problematic and very much out of sync with the historical roots of the land issue or it is just a matter of turning a blind eye to historical facts in pursuance of a certain narrative. The land issue remained a very critical concern and the longer it took to settle the more complicated it became; the more susceptible it was to instrumentalisation and to be high jacked by opportunistic elements making the consequences more dire. It is pertinent to highlight that the land issue was one of the central leitmotifs not only on the anti colonial discourse but also one of the main preoccupation of the post independence administration. Throughout the 1980s up to the late 1990s, the government expressed a strong desire to expropriate and redistribute land to the landless however because of various constraints and contradictions as alluded earlier on, policy traction was very negligible. From the Mephistophelean or Janus faced nature of the Lancaster House pact [38] and its moratorium on land expropriation to the various constitutional constraints, poor funding and ultimately the British retraction from their colonial obligations to fund expropriation, the government always expressed desire to redistribute land.

Some of the major reasons cited as explanation for the slow pace of redistribution was that the lack of adequate funding to effect a wholesale redistribution exercise. While exact figures of the pledges from the United States government and the United Kingdom and other International development partners like the WB have been very elusive, what is on the record is that only 40 million pounds sterling was disbursed by the British government [10]. It was a substantial amount but not enough and from then on funding was not forthcoming amid allegations by the British government that their Zimbabwean counterparts were misusing the funds and that land reform was captured by the elite for their own personal aggrandizement. Fast forward to the infamous letter to the Government of Zimbabwe (GoZ) by the then British Secretary of State for International Development, Clare Short in 1997 in which she reiterated that the Labour government had no links to colonial interests and henceforth they had no special responsibility to meet the costs of land redistribution. She exclaimed that, "we are a new government from diverse backgrounds without links to former colonial interests. My own origins are Irish and as you know we were once colonized not colonizers". Therefore, to label land expropriation and redistribution in Zimbabwe as a product of wicked political calculations and populist machinations whose only purpose was political mileage and power retention is not only treacherous and deceitful but also hypocritical and ignorant.

At this juncture, holding other factors constant, it is imperative to point out that what happened at the turn of the millennia in Zimbabwe was a Revolution and that the transition from settlerism not only in Zimbabwe but even in Latin America happens under a great deal of violence in view of the racial, emotive 
and epistemic character of land alienation. The structural exclusion of white capitalist agriculture from competitive black peasants and the barricading of access to land, markets and labor to them distorted whatever natural process of primitive accumulation might have occurred in the late $19^{\text {th }}$ and early to mid- $20^{\text {th }}$ century Rhodesia. The genesis of majority rule opened the floodgates for the process to be corrected, even though it usually takes place with a great deal of violence and in a multitude of forms. In 1927 Mao Zedong noted in his celebrated Investigation into the Peasant Question in Hunan that, revolutions are seldom leisurely, gentle, temperate, kind or restrained and magnanimous. They are insurrections, underpinned by violence wherein class struggles lead to an overthrow of the dominant by the hitherto marginalized cohorts [40]. Therefore, revolutionary changes that challenge colonially rooted racially prejudiced political economy of domination and placing land and other productive sectors of the economy into the hands of indigenes for the first time in centuries deserve proper recognition rather than dismissing them because of their failure to meet certain criteria. It the undeniable truth that no land reform can extinguish rural poverty completely or distribute land equitably and simultaneously, various constraints always abound, other groups will entirely miss the piece of the cake and the means to the end does not automatically become the end in itself.

Because of the binary approach to land reform as either populist or restitutive, the discourse of land redistribution in Zimbabwe has become a sordid polarized debate between on the one hand, a laudatory admiration of the exercise as a blueprint for social, political and economic emancipation. And on the other hand, a vehement attack on the program as nothing other than an instrumentalised policy, populist demagoguery sugar coated with a perverted and corrupted form of nationalism all contrived for political mileage. Such a binary, self righteous and "hear no evil see no evil" perspective continues to trump empirical analysis and analytical rigour by hollowing the middle ground between these contested positions. In some scholarly circles, the ZANU PF is portrayed as the epitome par excellence of the fight against the machinations and imperial designs of neo colonialism, and the Western denunciation of the affirmative exercise is depicted as visible signs of the depth of global anti black racism and imperialist gangsterism, a reluctance by imperialist forces to take stock and responsibility for its checkered past by acknowledging the need for racial justice [38]. On the contrary, land redistribution in Zimbabwe is viewed as nothing more than a product of megalomania, authoritarianism and populism within a power retention matrix. It is dismissed as a racially prejudiced and "reverse racist" pogrom against the Zimbabwean white community. It is depicted as a cynical sideshow carefully designed to divert attention from the regime's failure to provide economic and material deliverables to its citizenry [35]. Land redistribution is denounced for its governance deficit, its total disregard of property rights, its violence and haphazard implementation style.

As elucidated earlier, the paper argues that, these divergent strands of argument while seemingly polarized are very relevant and to some considerable de- 
gree have to be interrogated outside their contested polarized setting. Land redistribution is an inevitable and sacrosanct process in post settler polities because of the urgent demand for restitution and racial justice "which can" be a springboard from whence significant structural transformation in rural livelihoods can be realized which is central to poverty alleviation and ultimately socio-economic development. In the same vein however, proper land redistribution should ensure production sustainability in the short to medium term and most importantly should guarantee rights and redress. In the end, the discourse of land redistribution in Zimbabwe should graduate beyond this narrow autochthonous dogma to locate itself within the broader forces of international political economic arena with its various obligations and expectations for global development.

\section{Conclusions}

In summation, the paper made an analysis of the divergent strands of argument as to whether land redistribution was effected solely for the purpose of correcting historical injustice courtesy of colonialism or whether it signified the desperate attempts by the ruling party to regain some legitimacy under duress. The paper traced the genesis of Zimbabwe's land question within the country's transition from colonial to post colonial times and how exogenous and endogenous factors played out at critical junctures in the polity's history. The dawn of independence presented a perfect opportunity for the restructuring of the colonial structures of domination and its supporting logics. However, contrary to expectation, the transition of most post colonies is fraught with many contradictions and competing and conflicting policy demands. While affirmative action was appealing, sustainability and continuity were also equally important and it was within this eclectic atmosphere that land redistribution was to be carried out.

Post colonial literature has attempted to explain the nature of the post colonial state as a haven par excellence of corruption and patronage with "you scratch my back, I scratch yours" being the unspoken slogan by sufferance. Hero worship and messianic cult status were accommodated which did not leave any room for criticism and the struggle consciousness created a corrosive sense entitlement ultimately leading to poor governance [41]. This benefitted the liberator and his acolytes thereby instrumentalising race, policy and violence all in the pursuit of accumulation. The pursuit of power became a zero sum affair and as Bucheli and Dekker posited, economic policy became a contingent of patronage to the extent that from time to time it provided fresh booty into the network [33].

As the euphoria and memory of the liberation narrative become a distant memory because of generational transition and the changes in the demographic dividend, that which buoyed legitimacy and populism during the first years of liberation fades. State legitimacy becomes a function of tangible socio-economic deliverables which in most cases is elusive and in the event that the state fails to 
inculcate the perceived ethos and values of the liberation in the new generation (which is obvious), a great fissure is created within the polity. That strong belief in the rightness of their cause ignites a redefinition of history, creating patriots and sellouts, nationalists and western stooges, sons of the soil and saboteurs combatively creating a virulent patriotic and nationalist approach to politics that divides the polity into two "publics".

Thus, in light of above, land reform in Zimbabwe was never an event but a process that requires an appreciation of both internal and external dynamics as they played out at various stages in the country's post colonial transition. As was at Lancaster, the land issue required joint and concerted efforts not only from the former colonial power but also from the new administration in Harare and also from white LSCF. Similarly important, the Administration in Harare was supposed to realize that a successful land reform could only be beneficial to the country and its citizenry which should have informed redistribution particularly the FTLRP. White farmers should have cooperated with the government and not to hide behind neo liberal catechisms of property rights and compensation on such an emotive fault line [31].

The trajectories and rationalities that defines Zimbabwe's land policy fits into that narrative like a chip of the puzzle according to certain literature that depicts the land reform as an instrumentalised policy for political mileage, devoid of any economic rationality [25] [26] [28] [29] [30] [32]. The discourse surrounding land in Zimbabwe has created so much contestation and political polarization not only in Zimbabwe but also in neighboring countries within the region that share a colonial settler heritage (South Africa and Namibia included). It is therefore no doubt that land redistribution continues to be an emotive subject in Africa an amongst post settler economies across the global South largely because of the omnipresent shadow of colonial modernity and its epistemic tendencies and the resultant restitutive threshold appeal.

\section{Acknowledgements}

The author is very grateful to the supervisory support of Professor Lin Ye of the School of Government, Sun Yat-sen University during the authorship of this Article.

\section{Conflicts of Interest}

The author declares no conflicts of interest regarding the publication of this paper.

\section{References}

[1] Ndlovu-Gatsheni, S.J. (2015) Mugabeism?: History Politics and Power in Zimbabwe: African Histories and Modernities. Palgrave Macmillan, New York.

[2] Moyo, S. (2011) Three Decades of Agrarian Reform in Zimbabwe. The Journal of Peasant Studies, 38, 493-531. https://doi.org/10.1080/03066150.2011.583642 
[3] Rodney, W. (1972) How Europe Underdeveloped Africa. Bogle L'Ouverture, London.

[4] Ranger, T.O. (1960) Crisis in Southern Rhodesia. Fabian Commonwealth Research Series 217. Fabian Commonwealth Bureau.

[5] Kwashirai, V.C. (2006) Dilemmas in Conservationism in Colonial Zimbabwe, 1890-1930. Journal of Conservation and Society, 4, 541-561.

[6] Samasuwo, N. (2003) Food Production and War Supplies: Rhodesia's Beef Industry during the Second World War, 1939-1945. Journal of Southern African Studies, 29, 487-502. https://doi.org/10.1080/03057070306206

[7] Dashwood, H.S. (2000) Zimbabwe: The Political Economy of Transformation. University of Toronto Press, Toronto, Buffalo, London. https://doi.org/10.3138/9781442683792

[8] Alden, P. and Makumbe, J. (2001) The Zimbabwe Constitution: Race, Land Reform and Social Justice. In: Cornwell, H.G. and Stoddard, E.W., Eds., Global Multiculturalism, Rowman and Littlefield, Lanham, 215-237.

[9] Alexander, J. (2006) The Unsettled Land: State-Making and the Politics of Land in Zimbabwe 1893-2003. James Currey, Oxford.

[10] Moyo, S. and Yeros, P. (2005) Reclaiming Land: The Resurgence of Rural Movements in Africa, Asia and Latin America. Zed Books, London.

[11] Clapham, C. (2012) From Liberation Movement to Government: Past Legacies and the Challenges of Transition in Africa. The Brenthurst Foundation Discussion Paper.

[12] Albertus, M. (2015) Autocracy and Redistribution: The Politics of Land Redistribution. Cambridge University Press, New York. https://doi.org/10.1017/CBO9781316227107

[13] Bernstein, H. and Byres, T.J. (2001) From Peasant Studies to Agrarian Change. Journal of Agrarian Change, 1, 1-56. https://doi.org/10.1111/1471-0366.00002

[14] Moyo, S. (1995) A Gendered Perspective of the Land Question. Southern African Feminist Review, 1.

[15] Moyana, H.V. (1984) The Political Economy of Land in Zimbabwe. Mambo, Gweru.

[16] Tshuma, L. (1997) Colonial and Post-Colonial Reconstructions of Customary Land Tenure in Zimbabwe. Journal of Social Legal Studies, 7, 77-95. https://doi.org/10.1177/096466399800700105

[17] Palmer, R. (1990) Land Reform in Zimbabwe. 1980-1990. African Affairs, 89, 163-181. https://doi.org/10.1093/oxfordjournals.afraf.a098283

[18] Ranger, T.O. (1985) Peasant Consciousness and Guerilla War in Zimbabwe: A Comparative Study. James Curry, London.

[19] Stoneman, C. and Cliffe, L. (1989) Zimbabwe: Politics, Economics and Society. Pinter Publishers, London, New York.

[20] Bond, P. (1998) Uneven Zimbabwe. A Study of Finance, Development and Underdevelopment. Africa World Press, Trenton, NJ.

[21] Mandaza, I. (1986) Zimbabwe: The Politics of Economic Transition. Dakar, Senegal, CODESRIA.

[22] Moyo, S. (2000) Land Reform under Structural Adjustment in Zimbabwe. Land Use Change in Mashonaland Provinces. Nordiska Afrika Institutet Uppsala.

[23] Pazvakavambwa, S. and Hungwe, V. (2009) Land Redistribution in Zimbabwe. In: Binswanger-Mkhize, H., Bourguignon, C. and Van de Brink, J.E.R., Eds., Agricul- 
tural Land Redistribution: Towards Greater Consensus on the "How", World Bank Publications, Washington DC, 137-168..

[24] Bond, P. and Manyanya, J. (2002) Zimbabwe's Plunge: Exhausted Nationalism, Neo-Liberalism and the Search for Social Justice. Weaver Press, Harare.

[25] Laurie, A.C. (2016) The Land Reform Deception: Political Opportunism in Zimbabwe's Land Seizure Era. Oxford University Press, Oxford.

[26] Meredith, M. (2002) Robert Mugabe. Power and Plunder in Zimbabwe. Public Affairs, London.

[27] Deininger, K. (2003) Land Policies for Growth and Poverty Reduction. World Bank, Washington DC.

[28] Sachikonye, L. (2003) From 'Growth with Equity' to 'Fast Track' Reform: Zimbabwe's Land Question. Review of African Political Economy, 30, 227-240. https://doi.org/10.1080/03056244.2003.9693496

[29] Raftopoulos, B., Hammar, A. and Jensen, S. (2003) Zimbabwe's Unfinished Business: Rethinking Land, State and Nation in the Context of Crisis. Weaver, Harare.

[30] Blair, D. (2002) Degrees in Violence. Robert Mugabe and the Struggle for Power in Zimbabwe. Continuum, London.

[31] McDermot Hughes, D. (2006) Whiteness in Zimbabwe: Race, Landscape and the Problem of Belonging. Palgrave Macmillan, New York.

[32] Muzondidya, J. (2007) Jambanja: Ideological Ambiguities in the Politics of Land and Resource Ownership in Zimbabwe. The Journal of Southern African Studies, 33, 325-341. https://doi.org/10.1080/03057070701292616

[33] Bucheli, M. and Decker, S. (2002) Economic Nationalism in Latin America and Africa in the Twentieth Century: A Comparison.

[34] Matondi, P.B. (2012) Zimbabwe's Fast Track Land Reform Program. Zed Books, London, New York.

[35] Melber, H. (2015) In the Footsteps of Robert Gabriel Mugabe: Namibian Solidarity with Mugabe's Populism-(Bogus) Anti-Imperialism in Practice. In: Ndlovu-Gatsheni, S.J., Ed., Mugabeism?: History, Politics and Power in Zimbabwe, Palgrave Macmillan, New York, 107-120. https://doi.org/10.1057/9781137543462_7

[36] Ramose, M.B. (2002) Justice and Restitution in African Political Thought. In: Coetzee, P.H. and Roux, A.P.J., Eds., The African Philosophy Reader, 2nd Edition, Routeledge, New York, London, 461-463.

[37] Gordon, L.R. (1997) Existential Dynamics of Theorizing Black Invisibility. In: Gordon, L.R., Eds., Existence in Black: An Anthology of Black Existential Philosophy, Routledge, New York.

[38] Tafira, C.K. (2015) Mugabe's Land Reform and the Provocation of Global White Anti Black Racism: In: Ndlovu-Gatsheni, S.J., Ed., Mugabeism?: History, Politics and Power in Zimbabwe, Palgrave Macmillan, New York.

[39] Mbembe, A. (2001) On the Post Colony. University of California, Berkeley, CA.

[40] Mitter, R. (2007) Modern China: A Brief Insight. Sterling Publishing, New York, London.

[41] Herbst. J. and Mills, G. (2006) Big African States Wits University Press, Johannesburg. 